American Journal of Animal and Veterinary Sciences 4 (3): 42-48, 2009

ISSN 1557-4555

(C) 2009 Science Publications

\title{
Stressors Influence on Salmonella enterica Serovar Enteritidis Colonization in Broilers
}

\author{
${ }^{1}$ E.S. Soliman, ${ }^{1}$ E. Taha, ${ }^{1}$ K.D. Infante, ${ }^{1}$ K. Laboy, ${ }^{2}$ M.A. Sobieh and ${ }^{1}$ P.G. Reddy \\ ${ }^{1}$ Department of Pathobiology, College of Veterinary Medicine, \\ Nursing and Allied Health, Tuskegee University, Alabama, United States \\ ${ }^{2}$ Department of Animal Hygiene, Zoonoses and Animal Behavior, \\ College of Veterinary Medicine, Suez Canal University, Egypt
}

\begin{abstract}
Problem statement: Poultry industry usually exposing birds to a variety of actions and stressors includs fasting for gastrointestinal emptying before transportation and where birds are often exposed to high environmental temperature during the summer months. These environmental stressors may have influences on bird performance and susceptibility to pathogens such as Salmonella enteritidis by altering the intestinal micrbiota and changes in the gut integrity. Approach: This research was conducted to show that acute stressors in the poultry production can induce changes in the normal intestinal microbiota and epithelium structure and execratory functions, which may cause an increase in the opportunities of attachment of Salmonella enteritidis. Results: Experiments were conducted to determine the influence of $24 \mathrm{~h}$ feed withdrawal with $24 \mathrm{~h}$ exposure to high temperature $\left(30^{\circ} \mathrm{C}\right)$ on intestinal characteristics of broilers. Attachment of Salmonella enteritidis to ileal tissue was determined using an in vitro ileal loop assay. Changes in commensally intestinal microbial populations were determined using gel electrophoresis and alterations in ileal morphology were determined histologically. The results showed that attachment of Salmonella enteritidis to ileal tissues increased by $1.5 \operatorname{logs}\left(9.05 \log _{10}\right.$ Vs $7.59 \log _{10}$ Salmonella enteritidis/g of ileal tissue; $\left.p=0.0006\right)$ in broilers fasted for $24 \mathrm{~h}$ also, ileal tissues from birds subjected to $30^{\circ} \mathrm{C}$ for $24 \mathrm{~h}$ had increased the attachment of Salmonella enteritidis (8.77 $\log _{10}$ Vs $8.50 \log _{10}$ Salmonella enteritidis/g of ileum; $\mathrm{p}=0.01$ ) compared with birds held at $23^{\circ} \mathrm{C}$. Exposure to $30^{\circ} \mathrm{C}$ for $24 \mathrm{~h}$ also altered the microbial structure in the ileum and cecum. Where subjecting birds to $30^{\circ} \mathrm{C}$ for $24 \mathrm{~h}$ reduced the crypt depth $(6.0 \mathrm{Vs} 7.8 \mu \mathrm{m}$, respectively; $\mathrm{p}=0.002)$, but it had no effect on villus height or villus: Crypt ratio. Conclusion: The findings of the experiment explained the mechanisms by which stressors alters the normal intestinal characterization and induces susceptibility to enteric infection. Future work should focus on the use of prophylactic measures to reduce the stress conditions causing alteration of the intestinal microbiota and changes in gut integrity like considering the probiotic organisms the offer a promising solution for reducing pathogen colonization when fed orally.
\end{abstract}

Key words: Salmonella enteritidis, heat stress, microbial, colonization, broilers

\section{INTRODUCTION}

Salmonella is the leading cause of bacterial foodborne diseases in the United States and causes approximately 1.2 million cases of human Salmonellosis each year. The most commonly implicated source of food-borne Salmonellosis through consumption of undercooked poultry products, Antunes et al. ${ }^{[1]}$. Environmental stress has been shown to be a factor that may induce colonization of food animals by enteric pathogens, facilitate horizontal transmission of pathogens between animals, increase pathogen shedding and contribute in carcass contamination during processing ${ }^{[8,16]}$. Stress is an important consideration in poultry production; because birds are routinely subjected to stressors specially feed withdrawal and temperature fluctuations during transportation $^{[7,22]}$. Broilers are subjected to fasting to reduce the volume of intestinal contents before slaughter and thus minimize the risk of carcass contamination during processing; however, feed withdrawal has been associated with increased Salmonella colonization of the crop and intestine ${ }^{[18]}$. Exposure to extreme temperature is an additional

Corresponding Author: E.S. Soliman, Department of Pathobiology, College of Veterinary Medicine, Nursing and Allied Health, Tuskegee University, Alabama, United States 
stressor encountered in seasonal environments, during the summer months and is also associated with increased intestinal colonization and fecal shedding of pathogens in poultry ${ }^{[2]}$. The gastrointestinal tract is particularly responsive to stressors, which can cause a variety of changes as alteration of the normal, protective microbiota, Bailey and $\mathrm{Coe}^{[3,4]}$ and decreased integrity of the intestinal epithelium ${ }^{[21]}$. The commensal intestinal populations can protect the host from pathogen colonization by competing for epithelial binding sites and nutrients, strengthening the intestinal immune response and by producing antimicrobial bacteriocins $^{[11]}$. Therefore, stress-induced the integrity of the gut epithelium reduces innate protective mechanisms and may increase the potential for pathogens such as Salmonella to bind to and colonize the intestinal epithelium. Such colonization in poultry will increase the risk of carcass contamination during processing and will increase the potential for Salmonella to translocate to the reproductive tract, where it can contaminate eggs during formation.

\section{MATERIALS AND METHODS}

Birds: During feed withdrawal and heat stress experiments, 960 male and 308 broilers were housed to 24 floor pens by rate 40 birds/pen ${ }^{[23]}$. Birds were raised to 40-42 days of age on a standard corn-soybean meal diet. Initial ambient temperature was held at $35^{\circ} \mathrm{C}$ for the newly hatched chicks and then gradually decreased to $22^{\circ} \mathrm{C}$ by $21 \mathrm{st}$ day and held at $22^{\circ} \mathrm{C}$ for the duration of the experiment.

Stress conditions: (a) Feed Withdrawal: At 40 days old, 10 birds were randomly chosen, sacrificed in gas chamber and sampled. Feed was withdrawn $(0 \mathrm{~h})$ from the remaining flock and birds were kept on litter and given access to water for $4 \mathrm{~h}$ before being placed in transport crates for $20 \mathrm{~h}$. After $24 \mathrm{~h}$ of feed withdrawal, 10 additional birds were sacrificed and tissues were sampled. (b) Heat stress study: At 42 days, 20 birds were randomly chosen and 10 were immediately sacrificed and sampled, whereas the remaining 10 were subjected to $30^{\circ} \mathrm{C}$ temperature in floor pens for $24 \mathrm{~h}$, with full access to feed and water, before euthanasia and sampling.

Intestinal sampling: (a) Feed Withdrawal: A $10 \mathrm{~cm}$ section of the ileum was taken from each bird for an ileal challenge assay and was gently flushed with 0.05 M PBS. Tissue sections were immediately placed in ice-cold Dulbecco's Modified Eagle Medium + Lglutamine (DMEM) (Mediatech) and kept on ice until used for an in vitro Salmonella challenge assay as described below. (b) Heat Stress Study: Intestinal tissue and contents were obtained immediately after euthanasia and were collected as following: (1) $10 \mathrm{~cm}$ section of the ileum was taken for an in-vitro Salmonella challenge assay; (2) $3 \mathrm{~cm}$ ileal section, $13 \mathrm{~cm}$ from the ileo-cecal junction, was collected for gel electrophoresis analysis of microbial structure. Ileal tissues were opened and contents were gently removed, placed in microfuge tubes and immediately frozen at $-20^{\circ} \mathrm{C}$. Ileal tissues were gently flushed with $0.05 \mathrm{M}$ PBS and were frozen at $-20^{\circ} \mathrm{C}$; (3) $2 \mathrm{~cm}$ section of ileal tissue, $16 \mathrm{~cm}$ from the ileo-cecal junction, was collected for analysis of intestinal morphology, flushed with PBS and fixed in $10 \%$ neutral buffered formalin for $48 \mathrm{~h}$ and (4) $4 \mathrm{~cm}$ tissue section of the center of the cecum and cecal contents were obtained for Gel electrophoresis analysis.

Ileal loop assay for attachment of Salmonella enteritidis: (a) Challenge microorganism: Salmonella enterica serovar Enteritidis obtained and transferred with a kanamycin-resistance plasmid to allow selection in the presence of kanamycin. The stock culture was grown in Luria Bertani (LB) broth containing $50 \mu \mathrm{g}$ of kanamycin/mL (LB-kan) and stored with $20 \%$ (vol/vol) added glycerol. Fresh cultures were grown statically overnight in LB-kan broth, transferred to fresh LB-kan broth and grown overnight for the challenge study. Bacterial cells were harvested by centrifugation at $6,000 \times \mathrm{g}$ at $4^{\circ} \mathrm{C}$ for $15 \mathrm{~min}$ and were washed 3 times in equal volumes of sterile PBS. Cells were re-suspended in DMEM to an Optical Density (OD) 600 of 0.4 (approximately $1 \times 10^{6}$ cells $\mathrm{mL}^{-1}$ ). The inoculum was serially diluted and plated on LB broth to obtain the actual number of cells in the inoculum. (b) Ileal Loop Assay: In the organ culture ${ }^{[14]}$, the ileal sections were removed from DMEM, sealed at one end with $35 \mathrm{~mm}$ dialysis clamps and inoculated with approximately $6 \mathrm{~mL}$ of Salmonella enteritidis culture suspended in DMEM. The open end of the ileal section was sealed with dialysis clamps, the exterior was rinsed with PBS and the ileal loops were incubated in $100 \mathrm{~mL}$ of DMEM for $1 \mathrm{~h}$ at $37^{\circ} \mathrm{C}$ in a water bath in a $10 \% \mathrm{CO}_{2}$ atmosphere. After incubation, ileal contents were removed, the interior and exterior of each section was rinsed with PBS, tissues were homogenized, serially diluted in buffered peptone broth and plated on LB agar plates (Remel, Fisher Int.) containing $50 \mu \mathrm{g} \mathrm{mL} \mathrm{m}^{-1}$ kanamycin. Plates were incubated at $37^{\circ} \mathrm{C}$ for $24 \mathrm{~h}$ and were enumerated for Salmonella enteritidis. Differences due to feed withdrawal (0 Vs $24 \mathrm{~h}$ ) or heat stress were determined and analyzed using the GLM procedure in SAS. 
Intestinal morphology: After fixation in $10 \%$ neutral buffered formalin, a single $0.5 \mathrm{~cm}$ sample was cut from each ileal section, dehydrated with increasing concentrations (70, 80, 95 and 100\%) of ethanol, cleared with xylene (Thermo Sci Fisher Products, Fisher Int.) and placed into polyfin embedding wax. Tissue sections $(5 \mu \mathrm{m})$ were cut, floated onto slides, stained with hematoxylin (Thermo Sci Acros Organics, Fisher Int.) and eosin (Thermo Sci Acros Organics, Fisher Int.) and measured for villus height and crypt depth using light microscopy and a micrometer. Measurements for villi length were taken from the tip of the villus to the valley between individual villi and measurements for crypt depth were taken from the valley between individual villi to the basolateral membrane. Eight villi and villus-associated crypts were measured for each sample. Morphology data were analyzed using the GLM procedure in SAS.

DGGE: Genomic DNA was isolated from intestinal digesta and tissue samples using the Ultraclean Fecal DNA kit (Applied Biosystem), samples were diluted 1:1 with sterile distilled water and $0.25 \mathrm{~g}$ of the diluted sample was added to a bead beating tube containing beads, bead solution and lysis solution. Cells were lysed by a combination of detergent and mechanical action using a standard vortex. From the lysed cells, the released DNA was bound to a silica spin filter. The filter was washed and DNA was eluted using DNasefree Tris buffer. The DGGE was performed according to previously described methods with modification ${ }^{[13]}$, using bacteria-specific PCR primers to conserved regions flanking the variable V3 region of $16 \mathrm{~S}$ rDNA. Each PCR reaction mixture contained $0.02 \mathrm{nmol}$ of reverse primer (534r):5'-ATT ACC GCG GCT GCT GG-3' and $0.02 \mathrm{nmol}$ of forward primer with a GC clamp (341FGC): 5'CGC CCG CCG CGC GCG GCG GGC GGG GCG GGG GCA CGG GGG GCC TAC GGG AGG CAG CAG-3', 3.75 units of Taq DNA Polymerase, 5-10 ng of template DNA, $10 \times$ DNA Polymerase Buffer (containing $10 \mathrm{mM}$ Tris- $\mathrm{HCl}, 50$ $\mathrm{mM} \mathrm{KCl}$ and $0.1 \%$ Triton X-100) and $25 \mathrm{mM} \mathrm{MgCl}$. Amplifications were performed using a cephid smart cycler using the following program: (1) denaturation at $95^{\circ} \mathrm{C}$ for $5 \mathrm{~min}$; (2) subsequent denaturation at $95^{\circ} \mathrm{C}$ for $1 \mathrm{~min}$; (3) annealing at $65^{\circ} \mathrm{C}$ for $1 \mathrm{~min}$; (4) extension at $72^{\circ} \mathrm{C}$ for $1 \mathrm{~min}$;(5) steps $2-4$ repeated for 30 cycles; (6) denaturation at $95^{\circ} \mathrm{C}$ for $1 \mathrm{~min}$; (7) annealing at $55^{\circ} \mathrm{C}$ for $1 \mathrm{~min}$; (8) extension at $72^{\circ} \mathrm{C}$ for $1 \mathrm{~min}$; (9) steps 6-8 repeated for 7 cycles; (10) extension at $72^{\circ} \mathrm{C}$ for $7 \mathrm{~min}$; (11) $4.0^{\circ} \mathrm{C}$ final holding temperature. Polyacrylamide gels (8\% acrylamide-bisacrylamide ratio 37:5:1) were cast with a $40-60 \%$ urea: Deionized formamide gradient. The $100 \%$ denaturing acrylamide contained $7 \mathrm{M}$ urea and $40 \%$ deionized formamide. Amplified DNA was mixed with a $20 \%$ volume of $5 x$ loading buffer $(0.025 \%$ (wt/vol) bromophenol blue, $0.025 \%$ (wt/vol) xylene cyanol, 47\% (vol/vol) $0.1 \mathrm{M}$ EDTA and $47 \%$ (vol/vol) glycerol) and $20 \mu \mathrm{L}$ was loaded into each sample well (20-well comb). Gels were placed in a DCode Universal Mutation Detection System and electrophoresed in $0.5 x$ Tris-acetate-EDTA buffer at 60 for $10 \mathrm{~min}$ at $200 \mathrm{~V}$, followed by $16 \mathrm{~h}$ at $70 \mathrm{~V}$. Gels were silver stained ${ }^{[19]}$. Fragment pattern relatedness was determined using Bionumerics Software, which determined the number of bands per sample and similarity coefficients for banding patterns between pairs of samples. A distance matrix was calculated using the DICE function and dendrograms were constructed from this matrix using the Unweighted Pair Group Means Average (UPGMA) function. The degree of similarity of banding patterns between pairs of samples was represented as a similarity coefficient. All DGGE data were analyzed using the Mixed Model of SAS. Similarity coefficients between pairs of samples were segregated by treatment and similarity coefficients across treatments were used as an estimate of similarity assuming no treatment effect. Significance was determined using $\mathrm{p}$-value $<0.05$.

\section{RESULTS}

Effect of $\mathbf{2 4} \mathrm{h}$ feed withdrawal on ileal susceptibility to Salmonella enteritidis attachment: Intestinal tissues from fasted birds were more susceptible to pathogen attachment than tissues from control birds, with a 1.5 $\log$ increase $(\mathrm{p}=0.01)$ in Salmonella enteritidis associated with the ileal tissue of fasted birds compared with non fasted controls (Fig. 1).

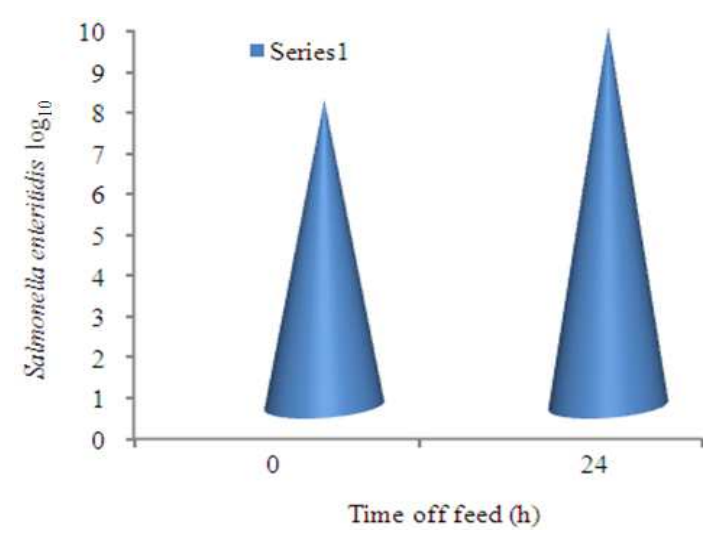

Fig. 1: Effect of $24 \mathrm{~h}$ feed withdrawal on in vitro Salmonella enteritidis attachment to broiler ileal tissue 
Table 1: Denaturing gradient gel electrophoresis similarity coefficients within control $\left(23^{\circ} \mathrm{C}\right)$ and acute heat-stress $\left(30^{\circ} \mathrm{C}\right.$ for $\left.24 \mathrm{~h}\right)$ treatments and across treatments (crossproducts)

\begin{tabular}{|c|c|c|c|c|}
\hline \multirow[b]{2}{*}{ Sample } & \multicolumn{4}{|c|}{ Treatment } \\
\hline & $22^{\circ} \mathrm{C}$ & $30^{\circ} \mathrm{C}$ & Cross-products & SEM \\
\hline Ileal contents & $68.0^{\mathrm{a}}$ & $55.4^{\mathrm{b}}$ & $41.7^{c}$ & 2.4 \\
\hline Ileal tissue & $73.7^{\mathrm{a}}$ & $72.5^{\mathrm{a}}$ & $46.3^{b}$ & 2.3 \\
\hline Cecal contents & $58.5^{\mathrm{a}}$ & $60.4^{\mathrm{a}}$ & $52.4^{\mathrm{b}}$ & 1.5 \\
\hline Cecal tissue & $53.4^{\mathrm{b}}$ & $64.7^{\mathrm{a}}$ & $44.5^{\mathrm{c}}$ & 2.8 \\
\hline
\end{tabular}

Table 2: Influence of heat stress on number of bands present in various intestinal systems of broilers as determined by gel electrophoresis

\begin{tabular}{llcr}
\hline & Treatment & & \\
Sample & $22^{\circ} \mathrm{C}$ & $30^{\circ} \mathrm{C}$ & SEM \\
\hline Ileal contents & 15.0 & 14.6 & 1.1 \\
Ileal tissue & $18.4^{\mathrm{a}}$ & $13.7^{\mathrm{b}}$ & 1.9 \\
Cecal contents & 18.5 & 19.4 & 1.3 \\
Cecal tissue & 10.7 & 8.9 & 2.0 \\
\hline a,b: Means within rows with & different & superscript & letters are \\
significantly different $(\mathrm{p}<0.05)$ & & &
\end{tabular}

Influence of an acute high temperature on intestinal susceptibility to Salmonella enteritidis adhesion, microbial populations and morphology of the small intestine of broilers: Broilers placed in the $30^{\circ} \mathrm{C}$ room showed behavioral signs of heat stress such as panting and spreading of wings. In the ileal loop assay, numbers of Salmonella enteritidis associated with the ileum were greater $(\mathrm{p}=0.0006)$ in heat-stressed birds $\left(8.77 \log _{10}\right.$ cfu $\mathrm{g}^{-1}$ ) compared with non stressed birds (8.50 $\log _{10}$ $\mathrm{cfu}^{-1}$ of ileum). Amplicon profiles for bacteria in the intestinal contents and tissues revealed differences in banding patterns between heat-stressed and non stressed birds. Birds held at $30^{\circ} \mathrm{C}$ exhibited lower $(\mathrm{p}=0.0001)$ similarity coefficients for microbial communities in ileal contents than did birds at $22^{\circ} \mathrm{C}$. In all intestinal samples, Table 1 , the similarity coefficients calculated across the 30 and $22^{\circ} \mathrm{C}$ treatments (cross-product) were lower $(\mathrm{p}=0.0001)$ than the similarity coefficients within individual treatments. The ileal tissue of heatstressed animals contained fewer $(\mathrm{p}=0.0251)$ amplicon fragments (bands) than the ileal tissue of non stressed birds, Table 2.

\section{DISCUSSION}

The ileal loop assays demonstrated that stress due to $24 \mathrm{~h}$ feed withdrawal and exposure to high temperatures is associated with increased susceptibility of intestinal tissues to Salmonella enteritidis colonization. Intestinal tissues from fasted birds had significantly greater attachment of Salmonella than did tissues from control birds, Fig. 1. Ramirez et al. ${ }^{[18]}$ in the study reported here, numbers of Salmonella enteritidis associated with the ileum were greater in heat-stressed birds $\left(8.77 \log _{10}\right.$ $\mathrm{cfu}^{-1}$ ) compared with non stressed birds (8.50 $\log _{10}$ cfu $\mathrm{g}^{-1}$ ileum), indicating that stress may contribute to increased intestinal colonization by Salmonella. Moreover heat stress may have damaging effects on mucosal structure ${ }^{[20]}$. In addition, heat shock proteins, whose expression can be induced by high ambient temperature and other environmental stressors, Lindquist and $\mathrm{Craig}^{[9]}$, may act as epithelial surface receptors for pathogen binding ${ }^{[24]}$.

There is a linear reduction in the mucus lining the intestinal tract over a $24 \mathrm{~h}$ fasting, as well as changes in intestinal morphology ${ }^{[23]}$. Hinton et al. ${ }^{[6]}$ showed that there were increases in intestinal Enterobacteriaceae and cecal aerobes with a concurrent decrease in lactic acid bacteria in broilers subjected to a $24 \mathrm{~h}$ feed withdrawal. Neurohormones associated with stress can increase growth and virulence factor expression in microbes including Escherichia coli, Yersinia enterocolitica and Pseudomonas aeruginosa in vitro ${ }^{[17]}$. Release of norepinephrine in the intestinal tract increased the number of gram-negative bacteria within the lumen ${ }^{[10]}$. One possible limitation of analyzing similarity coefficients within treatments is that each treatment analysis is separate; thus, one may end up with numerically comparable similarity coefficients, but banding patterns within treatment may differ, as the data from ileal tissue, Table 1 shows the dendrogram shows that banding patterns were highly similar within each treatment, with similarity coefficients of 73.7 and 72.5 for birds at 22 and $30^{\circ} \mathrm{C}$, respectively. However, the banding patterns are obviously different between treatments.

The DGGE data show changes in the intestinal bacterial populations of birds subjected to heat-stress, as indicated by changes in similarity coefficients in intestinal tissue and contents and the decreased number of bands in the ileal mucosa of birds subjected to $24 \mathrm{~h}$ heat stress, Table 1 and 2. Bacterial communities in the ileal contents from birds at $30^{\circ} \mathrm{C}$ had lower similarity coefficients than in the ileal contents from birds at $22^{\circ} \mathrm{C}$ on contrary, bacterial communities in the cecal tissue of birds at $30^{\circ} \mathrm{C}$ had greater similarity values than those in birds at $22^{\circ} \mathrm{C}$, suggesting that the bacterial communities between birds were more similar. In all intestinal samples, the similarity coefficients across treatments were lower than the similarity coefficients within individual treatments, indicating that the intestinal microbial community structure was significantly changed when birds were exposed to high temperatures for $24 \mathrm{~h}$. 
American J. Animal \& Vet. Sci., 4 (3): 42-48, 2009

Table 3: Influence of heat stress on small intestinal morphological characteristics

\begin{tabular}{lccr}
\hline & Treatment & & \\
& - & & \\
Sample & $22^{\circ} \mathrm{C}$ & $30^{\circ} \mathrm{C}$ & SEM \\
\hline Villus height $(\mu \mathrm{m})$ & 450.0 & 390.0 & 27.6 \\
Crypt depth $(\mu \mathrm{m})$ & $78.0^{\mathrm{a}}$ & $60.0^{\mathrm{b}}$ & 5.1 \\
Villus: Crypt & 5.7 & 6.9 & 1.0 \\
Villus height $(\mu \mathrm{m})$ & 450.0 & 390.0 & 27.6 \\
\hline $\mathrm{a}, \mathrm{b}:$ Means within & rows with & different & superscript \\
significantly different $(\mathrm{p}<0.05)$ & & & \\
\end{tabular}

The ileal tissue from birds held at $30^{\circ} \mathrm{C}$ contained fewer amplicon fragments than the ileal tissue from birds at $22^{\circ} \mathrm{C}$, Table 2 , indicating that exposing birds to high temperatures for $24 \mathrm{~h}$ caused a reduction in microbial species associated with the ileal wall. Influence of $24 \mathrm{~h}$ heat stress on ileal morphology was evaluated. In birds subjected to heat stress, crypt depth was reduced $(p=0.002)$ compared with non stressed birds (60 Vs $78 \mu \mathrm{m}$, respectively; Table 3 . Villus height and the villus: Crypt ratio were unchanged in response to $24 \mathrm{~h}$ heat stress.

Birds subjected to $30^{\circ} \mathrm{C}$ for $24 \mathrm{~h}$ had reduced crypt depth compared with birds at $22^{\circ} \mathrm{C}$. Villus height and the villus: Crypt ratio were unchanged in birds exposed to $30^{\circ} \mathrm{C}$ this may be attributed to the short duration of the stressor and the resistance of the ileum to structural change compared with other regions of the small intestine; Yamauchi et al. ${ }^{[26]}$. It is likely that changes in cell proliferation would be observed first in the stem cells of the crypt rather than the villus because of the high proliferative activity of the crypt; Yamauchi et al. ${ }^{[26]}$. Morphological changes in response to fasting occur more rapidly in the proximal two-thirds of the small intestine than in the ileum. In feed withdrawal studies with chickens, the structure of the duodenum and jejunum mucosa changes rapidly, often within $36 \mathrm{~h}$ of the onset of stress, whereas the ileum maintains its normal morphology longer and requires extended periods of stress to influence its structure; Yamauchi et al. ${ }^{[26]}$. The findings from the $24 \mathrm{~h}$ heat stress study suggest that stressors could act in several ways to increase intestinal susceptibility to in vitro Salmonella enteritidis attachment; by disrupting the normal protective microbiota and altering intestinal morphology, stressors create an opportunity for pathogens to colonize the intestine. Probiotic organisms such as lactobacilli, some strains of $E$. coli and yeast offer promise for reducing pathogen colonization when fed orally ${ }^{[15,25]}$. When administered consistently, probiotic organisms can colonize and form a niche in the intestine and may be a useful dietary treatment if administered before feed withdrawal or transportation and processing. In addition, non digestible oligosaccharides, or probiotics, have been shown to enhance intestinal growth of probiotic or beneficial commensal organisms ${ }^{[5]}$. The fermentation of prebiotic complex carbohydrates by intestinal microbes produces volatile fatty acids, which promote epithelial cell proliferation and renewal ${ }^{[12]}$. Such activity may enhance integrity of the intestinal epithelium. Therefore, dietary supplementation of the flock with prebiotics before periods of anticipated stress may also limit the damage to the intestinal epithelium elicited by stressors.

\section{CONCLUSION}

The study revealed that acute stressors can invoke significant changes in the normal intestinal microbiota, intestinal morphology and in-vitro susceptibility for Salmonella Enteritidids attachment to the ileum in the broilers. Stressors can increase the intestinal susceptibility to in-vitro Salmonella Enteritidids attachment by disrupting the normal protective microbiota or by altering intestinal morphology and as end result it create an opportunity for pathogens to colonize in the intestine. Also acute stressors can evoke alteration in the mucous production and composition that can affect the attachment capability of both commensal and pathogenic micro-organisms.

All the information that were concluded can be important to be considered in the poultry industry as a step during designing on-farm strategies aiming to reduce the pathogen contamination in poutry.

\section{REFERENCES}

1. Antunes, P., C. Réu, J.C. Sousa, L. Peixe and N. Pestana, 2003. Incidence of Salmonella from poultry products and their susceptibility to antimicrobial agents. Int. J. Food Microbiol., 82: 97-103. DOI: 10.1016/S0168-1605(02)00251-9

2. Bailey, J.S., 1988. Integrated colonization control of Salmonella in poultry. Poult. Sci., 67: 928-932. http://www.ncbi.nlm.nih.gov/pubmed/3413018

3. Bailey, M.T. and C.L. Coe, 1999. Maternal separation disrupts the integrity of the intestinal microflora in infant rhesus monkeys. Dev. Psychobiol., 35: 146-155. http://www.ncbi.nlm.nih.gov/pubmed/10461128

4. Bailey, M.T., G.R. Lubach and C.L. Coe, 2004. Prenatal stress alters bacterial colonization of the gut in infant monkeys. J. Pediatr. Gastroenterol. Nutr., 38: 414-421.

http://journals.lww.com/jpgn/pages/articleviewer.a spx ?year $=2004 \&$ issue $=04000 \&$ article $=00009 \&$ typ $\mathrm{e}=\mathrm{abstract}$ 
5. Bouhnik, Y., L. Raskine, E. Vicaut, C. Neut and B. Flourie et al., 2004. The capacity of nondigestible carbohydrates to stimulate fecal bifido-bacteria in healthy humans: A double-blind, randomized, placebo-controlled, parallel-group, dose-response relation study. Am. J. Clin. Nutr., 80: 1658-1664.

http://cat.inist.fr/?aModele $=$ afficheN\&cpsidt $=16336653$

6. Hinton Jr., A., R.J. Buhr and K.D. Ingram, 2000. Physical, chemical and microbiological changes in the ceca of broiler chickens subjected to incremental feed withdrawal. Poult. Sci., 79: 483-488. http://www.ncbi.nlm.nih.gov/pubmed/10780642

7. Humphrey, T., 2006. Are happy chickens safer chickens? Poultry welfare and disease susceptibility. Br. Poult. Sci., 47: 379-391. DOI: 10.1080/00071660600829084

8. Isaacson, R.E., L.D. Firkins, R.M. Weigel, F.A. Zuckermann and J.A. Di Petrio, 1999. Effect of transportation and feed withdrawal on shedding of Salmonella typhimurium among experimentally infected pigs. Am. J. Vet. Res., 60: 1155-1158. http://cat.inist.fr/?aModele=afficheN\&cpsidt=10208999

9. Lindquist, S. and E.A. Craig, 1988. The heat-shock proteins. Ann. Rev. Genet., 22: 631-677. DOI: 10.1146/annurev.ge.22.120188.003215

10. Lyte, M. and M.T. Bailey, 1997. Neuroendocrinebacterial interactions in a neurotoxin-induced model of trauma. J. Surg. Res., 70: 195-201. http://cat.inist.fr/?aModele $=$ afficheN\&cpsidt $=2754$ 463

11. MacDonald, T.T. and G. Monteleone, 2005. Immunity, inflammation and allergy in the gut. Science, 307: 1920-1925. DOI: 10.1126/science. 1106442

12. Macfarlane, G.T., H. Steed and S. Macfarlane, 2008. Bacterial metabolism and health-related effects of galacto-oligosaccharides and other probiotics. J. Applied Microbiol., 104: 305-344. DOI: 10.1111/j.1365-2672.2007.03520

13. Muyzer, G. and K. Smalla, 1998. Application of Denaturing Gradient Gel Electrophoresis (DGGE) and Temperature Gradient Gel Electrophoresis (TGGE) in microbial ecology. Antonie Van Leeuwenhoek, 73: 127-141. DOI: 10.1023/A:1000669317571

14. Naughton, P.J., L.L. Mikkelsen and B.B. Jensen, 2001. Effects of nondigestible oligosaccharides on Salmonella enterica serovar Typhimurium and nonpathogenic Escherichia coli in the pig small intestine in vitro. Applied Environ. Microbiol., 67: 3391-3395. DOI: 10.1128/AEM.67.8.33913395.2001
15. Parvez, S., K.A. Malik, S.K. Ah and H.Y. Kim, 2006. Probiotics and their fermented food products are beneficial for health. J. Applied Microbiol., 100: 1171-1185. http://www.ncbi.nlm.nih.gov/pubmed/16696665

16. Poppe, C., 1999. Epidemiology of Salmonella enterica serovar Enteritidis. In: Salmonella enterica Serovar Enteritidis in Humans and Animals: Epidemiology, Pathogenesis and Control, Saeed, A.M., R.K. Gast, M.E. Potter and P.G. Wall (Eds.). WileyBlackwell, Ames, ISBN: 0813827078, pp: 3-18.

17. Rahman, H., R. Reissbrodt and H. Tschape, 2000. Effect of norepinephrine on growth of Salmonella and its enterotoxin production. Indian J. Exp. Biol., 38: 285-286.

http://www.ncbi.nlm.nih.gov/pubmed/10927876

18. Ramirez, G.A., L.L. Sarlin, D.J. Caldwell, C.R. Yezak Jr. and M.E. Hume et al., 1997. Effect of feed withdrawal on the incidence of Salmonella in the crops and ceca of market age broiler chickens. Poult. Sci., 76: 654-656. http://poultsci.highwire.org/cgi/content/abstract/76/ $4 / 654$

19. Sambrook, J., E.F. Fritsch and T. Maniatis, 1989. Molecular Cloning: A Laboratory Manual. 2nd Edn., Cold Spring Harbor Laboratory Press, Woodbury, New York. http://orton.catie.ac.cr/cgibin/wxis.exe/?IsisScript=LIBRO.xis\&method=post \&formato=2\&cantidad $=1$ \&expresion $=\mathrm{mfn}=006164$

20. Sengupta, A. and R.K. Sharma, 1993. Acute heat stress in growing rats: Effect on small intestinal morphometry and in vivo absorption. J. Therm. Biol., 18: 145-151. http://cat.inist.fr/?aModele $=$ afficheN\&cpsidt $=4842$ 037

21. Soderholm, J.D., D.A. Yates, M.G. Gareau, P.C. Yang, G. MacQueen and M.H. Perdue, 2002. Neonatal maternal separation predisposes adult rats to colonic barrier dysfunction in response to mild stress. Am. J. Physiol. Gastrointest. Liver Physiol., 283: G1257-G1263. DOI: 10.1152/ajpgi.00314.2002

22. St-Pierre, N.R., B. Cobanov and G. Schnitkey, 2003. Economic losses from heat stress by US livestock industries. J. Dairy Sci., 86: E52-77. http://jds.fass.org/cgi/content/abstract/86/13_suppl/ E52

23. Thompson, K.L. and T.J. Applegate, 2006. Feed withdrawal alters small-intestinal morphology and mucus of broilers. Poult. Sci., 85: 1535-1540. http://poultsci.highwire.org/cgi/content/abstract/85/ 9/1535 
24. Wampler, J.L., K.P. Kim, Z. Jaradat and A.K. Bhunia, 2004. Heat shock protein 60 acts as a receptor for the Listeria adhesion protein in Caco-2 cells. Infect. Immun., 72: 931-936. DOI: 10.1128/IAI.72.2.931-936.2004

25. Wehkamp, J., J. Harder, K. Wehkamp, B.W.V. Meissner and M. Schlee et al., 2004. NF- $\kappa$ B-and AP-1mediated induction of human beta defensin-2 in intestinal epithelial cells by Escherichia coli Nissle 1917: A novel effect of a probiotic bacterium. Infect. $\quad$ Immun., 72: 5750-5758. http://www.pubmedcentral.nih.gov/articlerender.fc gi? $\operatorname{artid}=517557$
26. Yamauchi, K., K. Yamamoto and Y. Ishiki, 1995. Morphological alterations of the intestinal villi and absorptive epithelial cells in each intestinal part in fasted chickens. Jap. Poult. Sci., 32: 241-250. http://rms1.agsearch.agropedia.affrc.go.jp/contents/ JASI/pdf/society/52-0333.pdf. 